\title{
A Value Chain Framework for Assessment of Sustainable Practices in Manufacturing Firms
}

\author{
Bhavya Pande ${ }^{1}$ and Gajendra Kumar Adil $^{1}$
}

\begin{abstract}
Manufacturers face the challenge of implementing and assessing sustainable practices in their organizations due to several factors including lack of availability of clear guidelines and tools. Porter and Kramer (2006) suggest a framework on how to capture the negative effects of an organization's primary and support value chain activities on the environment and society. In this paper, the framework suggested by them has been suitably modified to capture and organize sustainable practices relevant to manufacturing firms. Accordingly, a number of sustainable practices are identified through a detailed analysis of literature and incorporated in the developed framework. Further, in order to validate the potential of the proposed framework to be used as an assessment tool, feedback was sought from a senior level professional from an internationally acclaimed research center with experience and proficiency in conducting sustainability audits in textiles and leather industry. Going forward, the validated framework will be administered to assess sustainable practices in select manufacturing organizations. This study is a part of an ongoing research on assessment of sustainability in manufacturing organizations.
\end{abstract}

Keywords: Assessment of Sustainable Practices; Sustainable Value Chain Practices; Triple Bottom Line; Total Life Cycle Approach; Sustainable Manufacturing

\section{Introduction}

Manufacturing industry is one of the primary contributors to the global crisis of energy and raw material scarcity, growing $\mathrm{CO}_{2}$ emissions, air and water pollution along with rising health and safety problems. This calls for manufacturing firms across the world to implement sustainability; which aims at achieving a balance between economic development, environmental health and societal welfare. Such balance is widely referred to in literature as triple bottom line (TBL) performance in the environmental (Env), social (Soc) and economic (Eco)dimensions (Elkington, 1998).

Despite the burning need, implementation of Sustainable Manufacturing (SM) by companies has been unsatisfactory (Kulatunga et al. 2013; Alayon et al. 2017). This can be attributed to the presence of several endogenous and exogenous barriers such as lack of management support, lack of awareness on how to implement sustainability, lack of government regulations and support besides difficulty in operations and maintenance (Kulatunga et al. 2013; Nordin et al. 2014).

Most of the reported research on SM practices have focussed on a limited set of manufacturing activities that a firm performs. For example, Zailani et al. (2012) study sustainable packaging and environmental purchasing; Jawahir et al. (2006) discuss the concept of product design for sustainability and Metro Vancouver (2009) provides a detailed description on sustainable logistics. Such disjointed studies of SM practices hamper visualization of the bigger picture for being used as a comprehensive guideline to manufacturing firms in implementing SM (Kulatunga et al. 2013; Wang et al. 2015). 
Moreover, most of the studies mainly focus on the environmental dimension (Wang et al. 2015). Because the practices are not well mapped, justification for their impact on a firm's TBL performance remains unclear. (Despeisse et al. 2012).

Thus, the current state of research on SM practices points to the need of developing an exhaustive list of potential sustainable practices for manufacturing firms and identifying which TBL dimension each practice strives to improve. Literature also points out to the need for conceptualization of a comprehensive framework of sustainable practices that integrates flows of goods, information and money across the supply chain with the TBL dimensions (see, Oelze et al. 2018).

In this direction, Porter and Kramer (2006) proposed a value chain (VC) framework to assess the positive and negative impact of a firm's activities on the environment and society. The VC encompasses all the activities a firm engages in manufacturing and delivering its products ranging from primary activities, such as, in-bound logistics, manufacturing operations, out-bound logistics, marketing \& sales, after sales service to support activities, such as, product design, material procurement, human resource \& technology development plus firm infrastructure related practices. However, Porter and Kramer (2006) only provide a partial list of examples of VC activities for overcoming the negative consequences of manufacturing on the planet and its inhabitants.

Kulatunga et al. (2013) have presented potential SM options in alignment to TBL dimensions of sustainability, irrespective of the manufacturing sector. Their main objective was to develop a model that will assist in understanding the drivers and barriers behind implementation of SM options. Even though their idea of coming up with a generic model of SM options is worth appreciating, they have left enough scope for improvement of the list of these options as well as the broad categories under which they are placed.

This study builds on the work of both Porter and Kramer (2006) as well as Kulatunga et al. (2013). It aims at developing lists of potential sustainable practices for manufacturing firms, based on extant literature and organizing them around the VC framework.

The remainder of the paper is structured as follows; Section 2 presents a sustainable value chain practice (SVCP) framework suitable to manufacturing firms in line with Porter and Kramer (2006). Section 3 briefly describes the relevant literature. Section 4 presents a comprehensive list of potential sustainable practices in the domain of primary and support activities of VC, respectively. Section 5 provides insights from the expert feedback on the framework. Section 6 gives the conclusion and discusses the scope for future work.

\section{Sustainable Value Chain Practice Framework}

Hergert and Morris (1989) highlight that the three important characteristics of VC as a strategic planning tool are: (1) an emphasis on identifying the source of sustainable competitive advantage [in the VC activities]; (2) an insistence on the importance of complex linkages and interrelationships [between activities]; and (3) the identification of generic strategies which must be pursued consciously and coherently in the different value creating activities. Traditionally VC has been used to identify and analyze value created by different activities along the chain from the economic perspective only. However, it also provides a scope to capture and analyze value from the environment and social perspective as pointed out by Porter and Kramer (2006). Hence, in the 
context of sustainability assessment, VC can be seen as a promising framework as it offers an activity based view of a firm by systematically segregating all the activities a firm performs into primary and support activities.

Exhibit 1. Proposed Sustainable Value Chain Practice (SVCP) Framework.

\begin{tabular}{|c|c|c|c|c|c|}
\hline & \multicolumn{5}{|c|}{ 1.Sustainable Design } \\
[Product Design, Process Design] \\
\cline { 2 - 7 } \\
\cline { 2 - 7 }
\end{tabular}

In this paper, VC framework has been adopted with suitable modifications for conceptualization of potential sustainable practices for manufacturing firms (see Exhibit. 1). In primary and support activity domains, sustainable practice categories are defined corresponding to original model of Porter and Kramer (2006). Few adaptations are incorporated into the framework. The proposed framework (Exhibit. 1) includes 'Reverse Logistics' as an additional primary practice category in consonance with total life cycle approach of sustainable manufacturing, according to which sustainability considerations should be taken at all the stages of a product's life cycle right from raw material extraction to final disposal. (Jawahir et al. 2006). Also, in the support activity domain we have slightly modified the practice category nomenclature to make it conform to the sustainability context.

We have further divided each practice category into sub-categories as shown inside square brackets in Exhibit 1. It should be mentioned that these sub-categories have been arrived through a detailed analysis of publications that are referred to in Sections 3 and 4.

\section{Relevant Literature}

Researchers have stressed on the need for extensive analysis and documentation 
of SM practices (Despeisse et al. 2012; Alayon et al. 2017) as research in this area is sparse. For the purpose of this study, we conducted a literature survey in two-stages.

Exhibit 2. Representative Publications Identified through Literature Review.

\begin{tabular}{|c|c|}
\hline Source & Practice Categories used by Authors \\
\hline Jawahir et al. (2006) & Design for Sustainability,6 R Concept \\
\hline Metro Vancouver (2009) & Sustainable Logistics \\
\hline Despeisse et al. (2012) & $\begin{array}{l}\text { Energy Use, Air Emissions, Water Use, Material Use, } \\
\text { Material Waste }\end{array}$ \\
\hline Gunasekaran and Spalanzani (2012) & $\begin{array}{l}\text { Sustainability in Product/Process Design and Development, } \\
\text { Sustainable Business Development, Sustainability in Supply } \\
\text { Operations, Sustainability in Production Operations, } \\
\text { Sustainability in Distribution Chain Operations, Sustainability } \\
\text { through Reverse Logistics }\end{array}$ \\
\hline Singh and Pandey (2012) & Green Marketing \\
\hline Zailani et al. (2012) & Environmental Purchasing, Sustainable Packaging \\
\hline Kulatunga et al. (2013) & Supply Chain, Product, Built Environment, Process \\
\hline Wichaisri and Sopadang (2013) & Sustainable Logistics \\
\hline Wang et al. (2015) & Green, Economic and Social Practices \\
\hline Hassan et al. (2015) & $\begin{array}{l}\text { Environmental Stewardship, Social Well-being, Economic } \\
\text { Growth }\end{array}$ \\
\hline Habidin et al. (2015) & $\begin{array}{l}\text { Manufacturing Processes, Supply Chain Management, Social } \\
\text { Responsibility, Environment Management }\end{array}$ \\
\hline Sirisawat et al. (2015) & Reverse Logistics \\
\hline Garg (2015) & Green Marketing \\
\hline Singhry (2015) & $\begin{array}{l}\text { Sustainable Sourcing, Sustainable Product Design, } \\
\text { Sustainable Manufacturing/Production, Sustainable } \\
\text { Packaging, Sustainable Transportation, Sustainable } \\
\text { Consumption, Reverse Logistics }\end{array}$ \\
\hline Castaneda and Trussart (2016) & Sustainability Standards and Certifications \\
\hline Rashid et al. (2017) & $\begin{array}{l}\text { Product Design and Development, Manufacturing Process, } \\
\text { Supply Chain Management, End of Life Management }\end{array}$ \\
\hline Alayon et al. (2017) & $\begin{array}{l}\text { Practices based on 9 LCSP (Lowell Center for Sustainable } \\
\text { Production) Principles }\end{array}$ \\
\hline Dangelico and Vocalelli (2017) & Green Marketing \\
\hline Gupta et al. (2018) & $\begin{array}{l}\text { Sustainable Product Process Design, Lean Practices, Agile } \\
\text { Practices, Sustainable Supply Chain Operations and } \\
\text { Distribution, Product Recovery and Return }\end{array}$ \\
\hline Gruchmann et al. (2018) & $\begin{array}{l}\text { Sustainable Purchasing, Sustainable Transportation, } \\
\text { Sustainable Warehousing, Sustainable Packaging, Reverse } \\
\text { Logistics }\end{array}$ \\
\hline Chowdhury and Yasmin (2018) & $\begin{array}{l}\text { Waste Management, Sustainable Manufacturing Process, } \\
\text { Sustainable Materials }\end{array}$ \\
\hline
\end{tabular}

First, we followed a manual process, through cross-referencing and basic keyword search on practice category names (included in Exhibit 1) as well as on "thesis on sustainable manufacturing practices" and "sustainable manufacturing practices" on popular search engines. This yielded 14 relevant publications. Subsequently, we conducted a more 
exhaustive literature search using Scopus database. In this search, we used keywords on practice category names derived from SVCP framework and one general keyword as, "sustainable manufacturing practices". This step fetched a total of 776 articles. Further, these articles were scrutinized and progressively eliminated to 120, 33 and 13 articles through evaluation of title, abstract and full paper, respectively. On comparing these 13 with that of the 14 obtained through manual search, we found an overlap of 6 papers. Thus, we got a total of 21 (14+13-6) representative publications for our study (see Exhibit 2).

We then examined each of these selected publications and extracted the SM practice categories as reported by authors in their articles (see Exhibit2, column 2). The extent of practices covered in each publication was further evaluated with respect to each practice category covered in the SVCP framework (refer to Exhibit 1). The extent of coverage represents the fraction of number of practices a particular publication mentions to the number of practices that would result if practices from all the publications of Exhibit 2 are considered together under each practice category (the actual listing of these practices based on these publications is presented in the next section).

Exhibit 3. Extent of Practices Covered in the Representative Publications.

\begin{tabular}{|l|c|c|c|c|c|c|c|c|c|c|c|}
\hline \multirow{3}{*}{ Source } & \multicolumn{7}{|c|}{$\begin{array}{l}\text { Extent of Coverage of Practices in VC Activity Domain } \\
\text { [Blank- Nil; L- Low; M-Medium; H- High] }\end{array}$} \\
\hline & \multicolumn{2}{|c|}{ Primary Activity Domain } \\
\hline & $\mathbf{1}$ & $\mathbf{2}$ & $\mathbf{3}$ & $\mathbf{4}$ & $\mathbf{5}$ & $\mathbf{6}$ & $\mathbf{1}$ & $\mathbf{2}$ & $\mathbf{3}$ & $\mathbf{4}$ & $\mathbf{5}$ \\
\hline Jawahir et al. (2006) & & L & & & & H & M & & & & \\
\hline Metro Vancouver (2009) & H & & H & & & H & & & & & \\
\hline Despeisse et al. (2012) & & M & & & & & & & & & \\
\hline Gunasekaran and Spalanzani (2012) & M & M & M & L & & M & M & M & & & \\
\hline Singh and Pandey (2012) & & & & H & & & & & & & \\
\hline Zailani et al. (2012) & & & L & & & & & H & & & \\
\hline Kulatunga et al. (2013) & L & M & M & & & L & M & M & M & M & \\
\hline Wichaisri and Sopadang (2013) & L & & L & & & & & & & & \\
\hline Wang et al. (2015) & L & & L & & L & L & L & & L & M & M \\
\hline Hassan et al. (2015) & & L & L & & & & L & M & & M & M \\
\hline Habidin et al. (2015) & & M & L & & & L & & M & L & & \\
\hline Sirisawat et al. (2015) & & & & & & H & & & & & \\
\hline Garg (2015) & & & & M & & & & & & & \\
\hline Singhry (2015) & M & M & M & & & H & M & M & L & & \\
\hline Castaneda and Trussart (2016) & & & & & & & & & L & & \\
\hline Rashid et al. (2017) & M & M & M & & L & M & M & M & M & & \\
\hline Alayon et al. (2017) & & H & & & & H & H & & M & H & H \\
\hline Dangelico and Vocalelli (2017) & & & & M & & & & & & & \\
\hline Gupta et al. (2018) & M & M & M & & & H & H & M & L & & \\
\hline Gruchmann et al. (2018) & M & & M & & & M & & & & & \\
\hline Chowdhury et al. (2018) & & H & L & & & M & M & & L & & \\
\hline
\end{tabular}

The extent of coverage of practices in the publications for each practice category of SVCP framework is categorized as Nil (Blank), Low (L), Medium (M) and High (H) in 
Exhibit 3. In Exhibit 3, columns 2-7 numbered as 1-6 in the primary activity domain and columns 8-12 numbered as 1-5 in support activity domain corresponds to the number assigned to practices in the proposed SVCP framework in Section 2. A broad observation from Exhibit 3 is that individually the authors have considered a limited number of practice categories according to the value chain activities of a firm and further within each category, the extent of coverage of practices varies between nil to high. However, it is evident from the table that all publications when put together provide a good coverage of all the VC practice categories.

This exercise first of all helped us in identifying appropriate practice sub-categories for the proposed SVCP framework and second, in combining scattered knowledge from the identified sources to develop a comprehensive list of potential sustainable practices for each sub-category of the SVCP framework.

The publications were also analysed to see if they have linked practices to TBL dimensions. Kulatunga et al., 2013 and Wang et al., 2012 have tabulated the practices related to each TBL dimension of sustainability separately. Despeisse et al., 2012, Zailani et al., 2012 and Wang et al., 2015 have carried out empirical studies to determine the impact of a set of practices on firm's TBL performance.

The literature review indicates that there is a scope to investigate what are the potential sustainable practices for manufacturing firms and how they impact the TBL performance of a firm.

\section{Potential Sustainable Practices for Manufacturing Firms}

In this section, we present the list of sustainable practices which is developed through analysis of literature. We have created a list of practice items for each practice sub-category shown in the proposed SVCP framework and have linked each practice item to the TBL dimension it may improve using our judgement. Sections (4.1) and (4.2) present primary category practices and support category practices respectively.

\subsection{Potential Sustainable Practices in Primary Activity Domain of VC}

Primary activity domain of VC directly aids in physical creation and disposal of products.

We have combined in-bound and out-bound logistics practices (1, 3 in the SVCP framework) into a single practice category in Exhibit 4 as they have common subpractices. The sustainable practices included in this category (see Exhibit 4) covers activities associated with warehouse $\&$ inventory management, inspection of materials (both inbound and outbound), packaging and transportation. The sustainable practices included in Exhibit 5 covers manufacturing activities associated with transforming raw materials into final products. The sustainable practices included in Exhibit 6 covers activities associated with product promotion, customer development, product labelling and product sales. The sustainable practices included in Exhibit 7 covers activities associated with providing after sales service to customers with the aim of enhancing the value of a product, such as spare parts management, customer complaint management, repair and maintenance. 
Exhibit 4. Sustainable Logistics Practices.

\begin{tabular}{|c|c|c|}
\hline $\begin{array}{l}\text { Practice Sub- } \\
\text { Category }\end{array}$ & Practice Items & $\begin{array}{c}\text { TBL } \\
\text { Dimensions }\end{array}$ \\
\hline \begin{tabular}{|l|} 
1.In-Bound \\
Inspection
\end{tabular} & $\begin{array}{l}\text { 1. Inspection of material to ensure it meets all the quality, } \\
\text { environmental, health \& safety requirements. }\end{array}$ & Env, Eco, Soc \\
\hline $\begin{array}{l}\text { 2.Out-Bound } \\
\text { Testing \& } \\
\text { Inspection }\end{array}$ & $\begin{array}{l}\text { 1. Pre-shipment inspection considering, product and packaging } \\
\text { quality, environmental, health \& safety requirements. }\end{array}$ & Env, Eco, Soc \\
\hline \multirow{5}{*}{$\begin{array}{l}\text { 3.Sustainable } \\
\text { Packaging }\end{array}$} & 1. Maximizing the use of renewable/recyclable packaging materials. & Env, Eco \\
\hline & 2. Cooperation with customers to use green packaging. & Env \\
\hline & 3. Ensuring that packaging is safe. & Soc \\
\hline & 4. Packaging is designed to optimise material and energy. & Env, Eco \\
\hline & 5. Recovery/recycling of the packaged material after use. & Env \\
\hline \multirow{12}{*}{$\begin{array}{l}\text { 4. Warehouse \& } \\
\text { Inventory } \\
\text { Management } \\
\text { (In-bound \& Out- } \\
\text { bound) }\end{array}$} & 1. Increasing energy efficiency of warehouse operations. & Env, Eco \\
\hline & $\begin{array}{l}\text { 2. Wherever possible, replacing hazardous material with non- } \\
\text { hazardous alternatives. }\end{array}$ & Env \\
\hline & $\begin{array}{l}\text { 3.For green field projects, selecting the site and situating the building } \\
\text { to minimize traffic and noise impacts on the community. } \\
\end{array}$ & Env, Soc \\
\hline & 4. Following non-violating labour exploitation and child labour rules. & Soc \\
\hline & $\begin{array}{l}\text { 5.Training employees on efficient workflow processes and } \\
\text { procedures. }\end{array}$ & Soc \\
\hline & $\begin{array}{l}\text { 6.Training warehouse workers on safe handling, proper storage } \\
\text { techniques and spill and leak prevention. }\end{array}$ & Soc \\
\hline & 7. Maintaining safe and healthy working conditions. & Soc \\
\hline & 8.Optimizing warehouse layout and workflow. & Eco \\
\hline & 9.Reducing inventory obsolescence or degradation. & Eco \\
\hline & 10.Automating inventory handling and management processes. & Eco, Soc \\
\hline & $\begin{array}{l}\text { 11.Implementing Just in time (JIT) Inventory management wherever } \\
\text { possible. }\end{array}$ & Eco \\
\hline & 12.Reusing existing building and sites wherever possible. & Eco \\
\hline \multirow{12}{*}{$\begin{array}{l}\text { 5.Transportation } \\
\text { (In-bound \& Out- } \\
\text { bound) }\end{array}$} & 1.Shifting to modes that use less fossil fuel. & Env \\
\hline & 2.Using reusable or recyclable shipping materials. & Env \\
\hline & $\begin{array}{l}\text { 3.Specifying fuel-efficient fleet technologies and design improvements } \\
\text { when sourcing new fleet vehicles, such as increased aerodynamics, } \\
\text { vehicle weight reductions, improved engine and transmission designs, } \\
\text { improved rolling efficiency of tires and more efficient accessories. }\end{array}$ & Eco, Env \\
\hline & 4.Providing driver training on fuel-efficient driving techniques. & Soc \\
\hline & $\begin{array}{l}\text { 5.Implementing driver incentive programs to reward or recognize fuel } \\
\text { efficiency gains or fuel-efficient driving techniques. }\end{array}$ & Soc \\
\hline & 6. Providing safe and healthy working conditions to employees. & Soc \\
\hline & \begin{tabular}{|l} 
7.Optimizing transportation loads and routes. \\
\end{tabular} & Eco \\
\hline & 8.Reducing unnecessary idling of delivery vehicles. & Eco \\
\hline & $\begin{array}{l}\text { 9.Performing regular preventive fleet maintenance and inspections, } \\
\text { including items like tire pressure, which should be checked frequently. }\end{array}$ & Eco \\
\hline & $\begin{array}{l}\text { 10.Scheduling freight delivery times to reduce traffic congestion } \\
\text { during peak periods. }\end{array}$ & Eco \\
\hline & $\begin{array}{l}\text { 11.Working with local suppliers to shorten inbound transport } \\
\text { distances. }\end{array}$ & Eco, Env \\
\hline & $\begin{array}{l}\text { 12.Investigating and influencing suppliers' transportation modes, } \\
\text { loading and routes for inbound materials to gain full benefits of } \\
\text { sustainable transportation. }\end{array}$ & Env, Soc \\
\hline
\end{tabular}


Exhibit 5. Sustainable Manufacturing Operations.

\begin{tabular}{|c|c|c|}
\hline $\begin{array}{l}\text { Practice Sub- } \\
\text { Category }\end{array}$ & Practice Items & $\begin{array}{c}\text { TBL } \\
\text { Dimensions }\end{array}$ \\
\hline \multirow{8}{*}{$\begin{array}{l}\text { 1. Waste } \\
\text { Management }\end{array}$} & 1.Installation of waste recovery system (e.g. Effluent Treatment Plant) & Env \\
\hline & 2.Training employees on waste management practices. & Soc \\
\hline & 3.Sale of rejected materials \& end-products. & Eco \\
\hline & 4.Re-use of materials. & Env, Eco \\
\hline & 5.Implementation of process waste management-reuse/recycling. & Env, Eco \\
\hline & 6.Implementation of lean wastes minimisation practices. & Eco \\
\hline & 7.Implementation of E-waste management practices & Env \\
\hline & 8.Recycled waste management & Env \\
\hline \multirow{4}{*}{$\begin{array}{l}\text { 2.Energy } \\
\text { Conservation }\end{array}$} & 1.Use of renewable/green energy. & Env \\
\hline & 2.Training employees on green energy. & Soc \\
\hline & 3.Use of energy efficient lighting. & Env \\
\hline & 4.Use of energy efficient machines. & Env \\
\hline \multirow{3}{*}{$\begin{array}{l}\text { 3.Pollution } \\
\text { Prevention }\end{array}$} & 1.Measures taken for reduction of noise pollution. & Env \\
\hline & 2.Measures taken for reduction of air pollution. & Env \\
\hline & 3.Measures taken for reduction of water pollution. & Env \\
\hline \multirow{4}{*}{$\begin{array}{l}\text { 4. Water } \\
\text { Conservation }\end{array}$} & 1.Reuse of water. & Env \\
\hline & 2.Rain-water harvesting. & Env \\
\hline & 3.Reduction in water consumption. & Env \\
\hline & 4.Company has zero discharge units. & Env \\
\hline $\begin{array}{l}\text { 5.Agile } \\
\text { Manufacturing }\end{array}$ & $\begin{array}{l}\text { 1.Use of processes, tools, and training to enable a firm to respond quickly to } \\
\text { customer needs and market changes while still controlling costs and quality. }\end{array}$ & Eco \\
\hline \multirow{3}{*}{$\begin{array}{l}\text { 6.Worker's } \\
\text { Health \& } \\
\text { Safety }\end{array}$} & 1.Safe working conditions. & Soc \\
\hline & 2.Safe material handling practices. & Soc \\
\hline & 3.Health and wellness effect considered in manufacturing operations. & Soc \\
\hline
\end{tabular}

Exhibit 6. Sustainable Marketing \& Sales Practices.

\begin{tabular}{|l|l|c|}
\hline $\begin{array}{l}\text { Practice } \\
\text { Sub-Category }\end{array}$ & Practice Items & \multicolumn{1}{|c|}{ TBL } \\
\hline \multirow{5}{*}{$\begin{array}{l}\text { 1.Product } \\
\text { Promotion }\end{array}$} & $\begin{array}{l}\text { 1.Promote sustainability credentials efficiently. } \\
\text { Provide electronic statements or billing by e-mail. } \\
\text { - Using e-marketing rather than paper-based direct mail. } \\
\text { - Offering downloadable publications to reduce print quantities and paper usage. } \\
\text { - Offering webcasting as an alternative to live events to reduce } \\
\text { representatives' travel. } \\
\text { - Printing on materials using processes such as waterless printing. }\end{array}$ & Env \\
\cline { 2 - 3 } & $\begin{array}{l}\text { 2.Educating customers on sustainable products and benefits. } \\
\text { 3.Incorporating sustainability guidelines for use and return on product labels. }\end{array}$ & Env, Soc \\
\cline { 2 - 3 } & $\begin{array}{l}\text { 4. Use of eco-labels. } \\
\text { 5.Sustainability claims in product promotion and advertisement. }\end{array}$ & Env, Soc \\
\hline \multirow{5}{*}{ 2.Product Sales } & $\begin{array}{l}\text { 1.Sustainability training to sales force. } \\
\text { 2.Customer development and training on sustainability (1st tier to final } \\
\text { consumer). }\end{array}$ & Soc \\
\hline & \begin{tabular}{l} 
3.Sustainability consideration in deciding location of Sales offices. \\
\cline { 2 - 3 }
\end{tabular} & Soc \\
\hline
\end{tabular}

Mention of spare parts management and customer complaint management practices was not found in the literature. These have been added by authors based on their understanding of after sales service function in exhibit 7. 
Exhibit 7. Sustainable After Sales Service Practices.

\begin{tabular}{|l|l|c|}
\hline $\begin{array}{l}\text { Practice } \\
\text { Sub-Category }\end{array}$ & Practice Items & $\begin{array}{c}\text { TBL } \\
\text { Dimensions }\end{array}$ \\
\hline $\begin{array}{l}\text { 1.Spare Parts } \\
\text { Management }\end{array}$ & 1.Sustainability considerations in spare parts sourcing. & Env, Eco, Soc \\
\cline { 2 - 3 } $\begin{array}{l}\text { 2.Customer Complaints } \\
\text { Management }\end{array}$ & $\begin{array}{l}\text { 2.Pasy availability of spare parts. (locally available) } \\
\text { Env, Eco, Soc }\end{array}$ & Soc \\
\hline & 2.Highly responsive customer complaints management. & Env, Eco, Soc \\
\hline 3.Repair \& Maintenance & $\begin{array}{l}\text { 1.Prolonging the service life of products or materials by } \\
\text { providing maintenance and services to customers. }\end{array}$ & Eco, Env \\
\hline
\end{tabular}

The sustainable practices included in Exhibit 8 covers activities associated with recovering, reusing, recycling, redesigning, remanufacturing and final disposal of a product after it completes one useful life.

Exhibit 8. Reverse Logistics Practices

\begin{tabular}{|l|l|c|}
\hline $\begin{array}{l}\text { Practice } \\
\text { Sub-Category }\end{array}$ & Practice Items & $\begin{array}{c}\text { TBL } \\
\text { Dimensions }\end{array}$ \\
\hline \multirow{5}{*}{ 1.Product Return } & $\begin{array}{l}\text { 1.Implementation of a proactive take-back program to reclaim products at } \\
\text { the end of their useful lives. }\end{array}$ & Env \\
\cline { 2 - 3 } & $\begin{array}{l}\text { 2.Implementation of a centralized return centre (CRC) devoted to sorting, } \\
\text { processing and shipping returned products to their next destinations. }\end{array}$ & Env \\
\cline { 2 - 3 } 3. Outsourcing reverse logistics to a third party. & Env \\
\hline \multirow{5}{*}{ 2.Post Return } & $\begin{array}{l}\text { 1.Assessing value of returned products and determining resale, reuse, or } \\
\text { recycling potential of the whole product. }\end{array}$ & Eco \\
\cline { 2 - 3 } $\begin{array}{l}\text { 2.Reconditioning and recycling returned products to recover value and } \\
\text { reduce waste. }\end{array}$ & $\begin{array}{l}\text { Env, Eco } \\
\text { lifedesigning and remanufacturing the product to serve a useful second }\end{array}$ & Env, Eco \\
\cline { 2 - 3 } & $\begin{array}{l}\text { 4.Disassembling and reclaiming any recyclable materials and safely dispose } \\
\text { of the remainder where reconditioning is not possible because of product } \\
\text { condition, legal, or environmental restrictions. }\end{array}$ & Env, Eco, Soc \\
\cline { 2 - 3 } $\begin{array}{l}\text { 5.Donating serviceable returned products to charitable organizations for } \\
\text { redistribution to those in need. }\end{array}$ & Soc, Env \\
\cline { 2 - 3 } & \begin{tabular}{l} 
6.Outsourcing the above activities to a third party. \\
Eco, Env \\
\hline
\end{tabular}
\end{tabular}

\subsection{Potential Sustainable Practices in Support Activity Domain of VC}

The basic aim of sustainable practices considered in the support activity domain of VC is to provide aid to primary activities for smooth execution of production and distribution functions.

Exhibit 9. Sustainable Design Practices.

\begin{tabular}{|l|l|c|}
\hline $\begin{array}{l}\text { Practice } \\
\text { Sub-Category }\end{array}$ & Practice Items & $\begin{array}{c}\text { TBL } \\
\text { Dimensions }\end{array}$ \\
\hline \multirow{4}{*}{ 1.Product Design } & 1.Design of products to eliminate the use of hazardous materials. & Env, Soc \\
\cline { 2 - 3 } & $\begin{array}{l}\text { 2.Use environmentally friendly materials (e.g. recyclable, biodegradable, } \\
\text { non-hazardous). }\end{array}$ & Env, Soc \\
\cline { 2 - 3 } & 3.Design for sustainable packaging. & Env \\
\cline { 2 - 3 } & 4.Design for recyclability. & Env \\
\cline { 2 - 3 } & 5.Design for re-manufacturability. & Env \\
\cline { 2 - 3 } & 6.Design for environmentally safe disposal. & Eoc \\
\hline
\end{tabular}




\begin{tabular}{|c|c|c|}
\hline $\begin{array}{l}\text { Practice } \\
\text { Sub-Category }\end{array}$ & Practice Items & $\begin{array}{c}\text { TBL } \\
\text { Dimensions }\end{array}$ \\
\hline & 7.Design in accordance to product sustainability standards/certifications. & Env, Soc \\
\hline & $\begin{array}{l}\text { 8.Use of product design techniques like green quality function deployment } \\
\text { (QFD). }\end{array}$ & Env \\
\hline & 9.Design for health and wellness. & Soc \\
\hline & 10.Design for operational safety/ safe working conditions. & Soc \\
\hline & 11.Design that incorporate reduction of material use. & Eco \\
\hline & 12.Design that facilitate repair, rework and refurbish. & Eco, Env \\
\hline & $\begin{array}{l}\text { 13.Design that facilitates disassembly of the waste product, separation of } \\
\text { the parts according to materials and reprocessing of materials. }\end{array}$ & Env \\
\hline & 14.Design for durability, maintainability and functional effectiveness. & Eco \\
\hline & 15.Design that reduces manufacturing cost. & Eco \\
\hline \multirow{8}{*}{ 2. Process Design } & 1.Design that incorporates principle of energy efficiency. & Env, Eco \\
\hline & 2.Design that incorporates principle of water efficiency. & Env \\
\hline & 3.Design that incorporates environmental considerations in material handling & Env \\
\hline & 4.Design that minimises pollution-air, water, land. & Env \\
\hline & 5.Design that uses green/energy efficient machines/equipments. & Env \\
\hline & 6.Use of environmental indicators to design and a process. & Env \\
\hline & 7.Use of social indicators to design a process. & Soc \\
\hline & 8.Design that reduces manufacturing cost. & Eco \\
\hline
\end{tabular}

The sustainable practices included in Exhibit 9 covers activities associated with product and process design. The sustainable practices included in Exhibit 10 covers activities associated with supplier selection and development as well as procurement of materials and machinery.

Exhibit 10. Sustainable Sourcing Practices.

\begin{tabular}{|c|c|c|}
\hline $\begin{array}{l}\text { Practice } \\
\text { Sub-Category }\end{array}$ & Practice Items & $\begin{array}{c}\text { TBL } \\
\text { Dimensions }\end{array}$ \\
\hline \multirow{8}{*}{$\begin{array}{l}\text { 1.Supplier } \\
\text { Selection }\end{array}$} & 1.Suppliers' environmental and social certifications verification. & Env, Soc \\
\hline & 2.Suppliers'environmental and social compliance auditing. & Env, Soc \\
\hline & 3.Second-tier suppliers' environmental and social compliance verification & Env, Soc \\
\hline & 4.Quality Assessment (check for certifications, test reports) & Eco \\
\hline & 5.Preference for local suppliers. & Env, Soc, Eco \\
\hline & 6.Lead time consideration. & Eco \\
\hline & 7.Cost consideration. & Eco \\
\hline & 8.Supply flexibility (round the year supply, unlimited supply). & Eco \\
\hline \multirow{7}{*}{ 2.Procurement } & 1.Procurement of recycled raw materials. & Env \\
\hline & 2.Procurement of recyclable and reusable raw materials \& accessories. & Env \\
\hline & 3.Procurement of recycled packaging material. & Env \\
\hline & 4.Procurement of recyclable and reusable packaging material. & Env \\
\hline & $\begin{array}{l}\text { 5.Procurement of energy efficient machinery or machinery with green } \\
\text { certificates/labels. }\end{array}$ & Env \\
\hline & \begin{tabular}{|l|} 
6.Procurement of biodegradable, non-hazardous, safe, restricted \\
substance list (RSL) compliant raw materials and chemicals.
\end{tabular} & Env, Soc \\
\hline & $\begin{array}{l}\text { 7.Procurement of packaging material considering human health and } \\
\text { safety considerations. }\end{array}$ & Soc \\
\hline \multirow{3}{*}{$\begin{array}{l}\text { 3.Supplier } \\
\text { Development }\end{array}$} & 1.Training suppliers on sustainability issues. & Soc \\
\hline & $\begin{array}{l}\text { 2.Joint effort/Collaboration with suppliers to improve their } \\
\text { sustainability performance. }\end{array}$ & Soc, Env \\
\hline & 3.Collaboration with reverse logistics providers. & Soc, Env \\
\hline
\end{tabular}


The sustainable practices included in Exhibit 11 covers activities associated with complying to standards and certifications as well as assessment and reporting of sustainability.

Exhibit 11. Sustainability Standards \& Systems Related Practices.

\begin{tabular}{|c|c|c|}
\hline \begin{tabular}{|l|} 
Practice \\
Sub-Category
\end{tabular} & Practice Items & $\begin{array}{c}\text { TBL } \\
\text { Dimensions }\end{array}$ \\
\hline \multirow{4}{*}{$\begin{array}{l}\text { 1.Sustainability } \\
\text { Assessment }\end{array}$} & $\begin{array}{l}\text { 1.Use of Environment, Social and Quality Compliance Certifications. } \\
\text { (e.g. ISO 9001, ISO 14001, Green leaf, occupational health and safety } \\
\text { related certificates, SA 8000, etc) }\end{array}$ & Env, Eco, Soc \\
\hline & 2. Use of Metrics / indicators/tool for sustainability evaluation. & Env, Eco, Soc \\
\hline & 3. Benchmarking practices. & Env, Eco, Soc \\
\hline & $\begin{array}{l}\text { 4.Manufacturing Process Audits } \\
\text { (Energy Audits, Waste Audits, Safety Audits, Integrated process audits, } \\
\text { Testing of material in flow at various stages of manufacturing.) }\end{array}$ & Env, Eco, Soc \\
\hline $\begin{array}{l}\text { 2. Sustainability } \\
\text { Reporting }\end{array}$ & 1. Sustainability reporting is practiced. & Env, Eco, Soc \\
\hline
\end{tabular}

The sustainable practices included in Exhibit 12 covers activities associated with employee care and development which is a step towards achieving social sustainability requirements.

Exhibit 12. Employee Development Practices.

\begin{tabular}{|l|l|c|}
\hline $\begin{array}{l}\text { Practice } \\
\text { Sub-Category }\end{array}$ & Practice Items & $\begin{array}{c}\text { TBL } \\
\text { Dimensions }\end{array}$ \\
\hline 1.Employee Training & 1.Practices that focus on employee training and development. & Soc \\
\hline 2.Emplyee Care \& Welfare & 1.Practices that focus on employee care and welfare. & Soc \\
\hline
\end{tabular}

The sustainable practices included in Exhibit 13 covers activities associated with local community development which is a step towards achieving social sustainability requirements.

Exhibit 13. Community Development Practices

\begin{tabular}{|c|c|c|}
\hline \begin{tabular}{|l|} 
Practice \\
Sub-Category
\end{tabular} & Practice Items & $\begin{array}{c}\text { TBL } \\
\text { Dimensions } \\
\end{array}$ \\
\hline $\begin{array}{l}\text { 1.Employment } \\
\text { Generation }\end{array}$ & 1.Employment generation in the local community. & Soc \\
\hline \multirow{4}{*}{ 2.CSR Activities } & 1.Initiatives for environmental protection. & Env, Soc \\
\hline & 2.Local community development practices. & Env, Soc \\
\hline & 3.Collborative CSR activities with firms operating in the same cluster. & Env, Soc \\
\hline & $\begin{array}{l}\text { 4.Shared value initiatives. } \\
\text { Note- This point has been taken from Porter and Kramer (2006) }\end{array}$ & Env, Soc, Eco \\
\hline
\end{tabular}

\section{Expert Feedback on the Proposed SVCP Framework}

An expert feedback was sought on the proposed SVCP framework to gain a practitioner's perspective on its potential as an assessment tool. Accordingly, a senior level professional from an internationally acclaimed research centre with experience and 
proficiency in conducting sustainability audits in textiles and leather industry was contacted and interviewed.

His opinion was sought on the organization scheme, exhaustiveness and implementation potential of the practices covered in the SVCP framework. For each practice item listed under each practice sub category (see Exhibit 4 to 13), he was asked whether he has seen evidence of the practice in any industry, if not then does he see implementation potential in the practice. Illustrations and justifications were provided by him for each of his response.

Based on the feedback, one practice item was added to the sub category, Water Conservation' under the practice category, 'Sustainable Manufacturing Operations' on having zero discharge units in companies as the expert suggested that it is becoming an important criterion in assessing environmental performance of firms. Zero discharge units ensure that waste water is completely treated and reused leading to zero discharge of it from the manufacturing plants.

The expert found the proposed SVCP framework to be comprehensive. However, for it to be developed as an assessment tool, an extensive empirical validation is required.

\section{Conclusion}

This study offers a framework and comprehensive lists for potential sustainable practices in line with value chain activities of a manufacturing firm. Going forward, the framework will be used to assess the extent of implementation of sustainable practices in select manufacturing case companies starting with textile manufacturing firms. The assessment will include understanding the factors affecting the extent of implementation of sustainable practices; impact of sustainable practices on a firm's TBL performance and selection of appropriate set of sustainable practices for manufacturing firms.

\section{Acknowledgment}

The authors wish to thank the anonymous expert who provided feedback on the framework presented in this study.

\section{References}

Alayon, C., Safsten, K., and Johansson, G. (2017). Conceptual sustainable production principles in practice: Do they reflect what companies do?.Journal of Cleaner Production, 141, 693-701.

Castaneda, L., and Trussart, N. (2016). Sustainability standards and certification: looking through the lens of Foucault's dispositive. Global Networks, 16 (4), 490-510.

Chowdhury, N., and Yasmin, J. (2018). A study on sustainable manufacturing practices in RMG industries of Bangladesh. Munich Personal RePEc Archive (MPRA), Paper No. 87104, accessed at https://mpra.ub.uni-muenchen.de/87104/1/MPRA paper 87104.pdf on 12 Dec 2018, 5 P.M, IST.

Dangelico, R.M., and Vocalelli, D. (2017). “Green Marketing”: An analysis of definitions, strategy steps, and tools through a systematic review of the literature. Journal of Cleaner Production, 165, 1263-1279.

Despeisse, M., Mbaye, F., Ball, P.D., and Levers, A. (2012) The emergence of sustainable manufacturing practices. Production Planning \& Control, 23 (5), 354-376. 
Elkington, J. (1998). Accounting for the triple bottom line. Measuring Business Excellence, 2(3), 18-22.

Garg, A. (2015). Green Marketing for Sustainable Development: An Industry Perspective. Sustainable Development, 23 (5), 301-316.

Gruchmann, T., Schmidt, I., Lubjuhn, S., Seuring, S., and Bouman, M. (2018). Informing logistics social responsibility from a consumer-choice-centered perspective. TheInternational Journal of Logistics Management.

Gunasekaran, A., and Spalanzani, A. (2012). Sustainability of manufacturing and services: Investigations for research and applications. Int. J. Production Economics, 140, 35-47.

Gupta, S., Dangayach, G.S., Singh, A.K., Meena, M.L., and Rao, P.R. (2018). Implementation of sustainable manufacturing practices in Indian manufacturing companies. Benchmarking: An International Journal, 25(7), 2441-2459.

Habidin, N.F., Zubir, A.F.D., Fuzi, N.M., Latip, N.A.M., and Azman, M.N.A. (2015). Sustainable manufacturing practices in Malaysian automotive industry: confirmatory factor analysis. Journal of Global Entrepreneurship Research, 5(14).

Hassan, M.G., Nordin, N., and Ashari, H. (2015). Sustainable Manufacturing Practices Implementation in Malaysia Industries. JurnalTeknologi, 77(4),49-56.

Hergert, M., and Morris, D. (1989). Accounting Data for Value Chain Analysis. Strategic Management Journal, 10(12), 175-188.

Jawahir, I.S., Dillon, Jr. O.W., Rouch, K.E., Joshi, K.J., Venkatachalam, A., and Jaafar, I.H. (2006). Total Life-Cycle Consideration in Product Design for Sustainability: A Framework for Comprehensive Evaluation. 10 th International Research/Expert Conference, TMT 2006.

Kulatunga, A.K., Jayatilaka, P.R., and Jayawickrama, M. (2013). Drivers and barriers to implement sustainable manufacturing concepts in Sri Lankan manufacturing sector. 11th Global Conference on Sustainable Manufacturing, (GCSM).

Metro Vancouver. (2009). Sustainable Supply Chain Logistics Guide. Accessed at https://www.buysmartbc.com/_Library/Resources/resource metrovancouver_supply chain gui de.pdf on 12 December 2018, 5 P.M, IST.

Nordin, N., Ashari, H., and Hassan, M.G. (2014). Drivers and Barriers in Sustainable Manufacturing Implementation in Malaysian Manufacturing Firms. Proceedings of the 2014 IEEE IEEM.

Oelze, N.,Brandenburg M., Janson C and Warasthe R. (2018). Applying Sustainable Supply Chain Management Frameworks to Two German Case Studies. IFAC PapersOnLine 51-30 (2018) 293296

Porter, M.E., and Kramer, M.R. (2006). Strategy and Society:The link between competitive advantage and corporate social responsibility. HBR.

Rashid, S.H.A., Sakundarini, N., Ariffin, R., and Ramayah, T. (2017). Drivers for the adoption of Sustainable Manufacturing Practices: A Malaysia Perspective. International Journal of Precision Engineering and Manufacturing, 18(11), 1619-1613.

Singh, P.B., and Pandey, K.K. (2012). Green Marketing: Policies and Practices for Sustainable Development. Integral Review-A journal of Management, 5(1),22-30.

Singhry, H.B. (2015). An extended model of sustainable development from sustainable sourcing to sustainable reverse logistics: A supply chain perspective. International Journal of Supply Chain Management, 4 (4), 115-125.

Sirisawat, P., Kiatcharoenpol, T., Choomrit, N., and Wangphanich, P. (2016). A study of reverse logistics practices: A case study of the computer parts industry in Thailand. IEEE International Conference on Industrial Engineering and Engineering Management,356-360.

Wang, Z., Subramanian, N., Gunasekaran, A., Abdulrahman, M.D., and Liu, C. (2015). Composite sustainable manufacturing practice and performance framework: Chinese auto-parts suppliers' perspective. Int. J. Production Economics,170, 219-233.

Wichaisri, S., and Sopadang, A. (2013) Sustainable logistics system: A framework and case study. IEEE International Conference on Industrial Engineering and Engineering Management, 1017-1021.

Zailani, S., Jeyaraman, K., Vengadasan, G., and Premkumar, R. (2012). Sustainable Supply Chain Management (SSCM) in Malaysia: A survey. Int. J. Production Economics, 140(1), 330-340. 